\title{
Haemolytic-Uraemic Syndrome
}

\author{
A Report of an Outbreak \\ MURIEL M. McLEAN, C. HILTON JONES, and D. A. SUTHERLAND \\ From the Royal Alexandra Hospital, Rhyl
}

The haemolytic-uraemic syndrome, first described by Gasser, Gautier, Steck, Siebenmann, and Oechslin (1955) has attracted increasing interest in recent years. A search of the published reports has revealed 150 cases which we consider to be examples of this syndrome, though described under a variety of names (Table I).

An epidemic of this disease has never been reported. In this paper we describe 10 cases occurring within a short period in a small area in North Wales. None of the cases demonstrated severe thrombocytopenia which has hitherto been accepted as a cardinal feature of the condition. Although the syndrome has been regarded as having a high mortality, only one of our patients died, and we consider it probable that less severe forms of the condition have previously escaped recognition.

\section{Case Reports}

The main clinical and laboratory findings in the 10 cases are summarized in Table II. In all of them the red cells showed abnormal morphology, anisocytosis, polychromasia, spherocytosis and poikilocytosis with the presence of irregularly contracted cells (acanthocytes) (Fig. 1).

Case 1. J.N., aged 6 weeks, was admitted to hospital on June 14, 1963. Pallor and refusal to feed were the main complaints, and he had no gastro-intestinal upset. Cerebral irritability was the outstanding feature. Anaemia was not severe and did not require treatment, but the red cells showed marked poikilocytosis and spherocytosis. Blood fragility was greatly increased but returned to normal when haemolysis ceased. The blood urea was not greatly raised and returned to normal within three months. Proteinuria lasted only a few days.

Two years after the onset of the illness he was a very bright healthy little boy and all laboratory findings were normal.

Case 2. S.R., aged 8 years, was admitted on July 3, 1963. She presented with haemolytic anaemia following

Received June 25, 1965. a gastro-intestinal upset in which fresh blood had been noted in her stools. Although the platelet count was not decreased, she had numerous bruises and petechiae on

TABLE I

Summary of 150 Cases of Haemolytic-Uraemic Syndrome

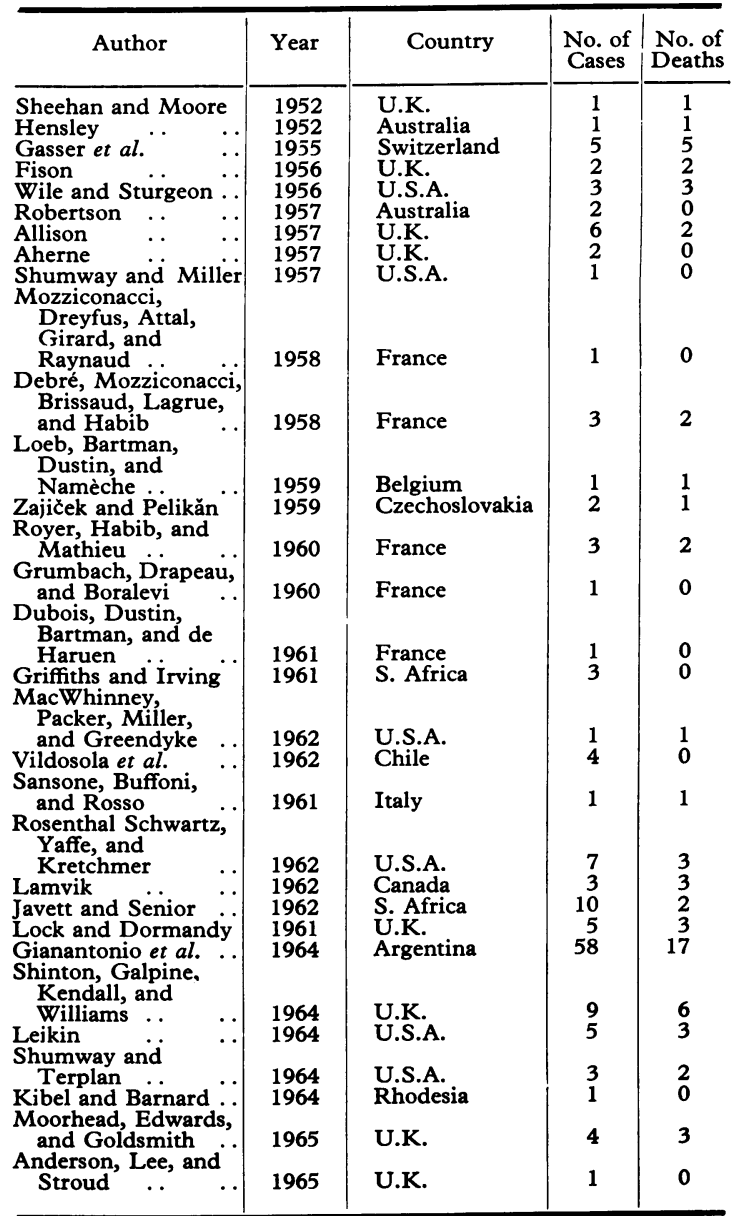


TABLE II

Laboratory and Clinical Findings in 10 Cases

\begin{tabular}{|c|c|c|c|c|c|c|c|c|c|}
\hline $\begin{array}{l}\text { Case } \\
\text { No. }\end{array}$ & Age & $\begin{array}{l}\text { Date of } \\
\text { Admission } \\
\text { in } 1963\end{array}$ & $\mathrm{Hb}(\%)$ & $\begin{array}{c}\text { Reticulo- } \\
\text { cytes } \\
(\%)\end{array}$ & $\begin{array}{l}\text { Platelets } \\
\text { per c.mm. }\end{array}$ & $\begin{array}{l}\text { White Cell } \\
\text { Count } \\
\text { per c.mm. }\end{array}$ & $\begin{array}{c}\text { Blood } \\
\text { Urea } \\
\text { (mg./ } \\
100 \mathrm{ml} .)\end{array}$ & Proteinuria & $\begin{array}{c}\text { Serum } \\
\text { Cholesterol } \\
\text { (mg./ } \\
100 \mathrm{ml} .)\end{array}$ \\
\hline $\begin{array}{r}1 \\
2 \\
3 \\
4 \\
5 \\
6 \\
7 \\
8 \\
9 \\
10\end{array}$ & $\begin{array}{l}6 \mathrm{wk} . \\
8 \mathrm{yr} . \\
2 \text { yr. } 3 \mathrm{mth} . \\
1 \text { yr. } 3 \mathrm{mth} . \\
10 \mathrm{mth} . \\
1 \mathrm{yr} .10 \mathrm{mth} . \\
2 \text { yr. } 9 \mathrm{mth} \text {. } \\
3 \text { yr. } 6 \mathrm{mth} . \\
11 \mathrm{mth} . \\
10 \mathrm{mth} .\end{array}$ & $\begin{array}{c}\text { June } 14 \\
\text { July } 3 \\
\text { July } 4 \\
\text { July } 8 \\
\text { July } 17 \\
\text { July } 18 \\
\text { July } 19 \\
\text { August } 7 \\
\text { August } 8 \\
\text { December } 13\end{array}$ & $\begin{array}{l}55 \\
35 \\
43 \\
61 \\
47 \\
53 \\
42 \\
46 \\
46 \\
30\end{array}$ & $\begin{array}{l}11 \\
14 \\
12 \\
20 \\
11 \\
14 \\
16 \\
24 \\
22\end{array}$ & $\begin{array}{l}215,000 \\
349,000 \\
238,000 \\
100,000 \\
193,000 \\
345,000 \\
+++++ \\
214,000 \\
134,000 \\
140,000\end{array}$ & $\begin{array}{r}25,800 \\
18,800 \\
26,600 \\
27,000 \\
18,400 \\
9,300 \\
14,800 \\
5,800 \\
38,700 \\
10,500\end{array}$ & $\begin{array}{r}52 \\
67 \\
550 \\
345 \\
130 \\
45 \\
74 \\
75 \\
96 \\
138\end{array}$ & $\begin{array}{c}+ \\
+ \\
++ \\
+++ \\
++ \\
+ \\
+ \\
+++ \\
+ \\
+\end{array}$ & $\begin{array}{l}\bar{Z} \\
\bar{Z} \\
305 \\
\bar{z} \\
448 \\
321\end{array}$ \\
\hline
\end{tabular}

her limbs, and, though there were no urinary symptoms, the blood urea was $67 \mathrm{mg} . / 100 \mathrm{ml}$. and proteinuria was found.

After an initial blood transfusion haemolysis continued but ceased when treatment with prednisolone was given. Proteinuria decreased while she was having prednisolone, but recurred when this was discontinued and persisted for six months.

Two years after the onset of the illness she was well and all laboratory investigations were normal.

Case 3. H.B., aged 2 years 3 months, was admitted on July 4, 1963 because of continued vomiting following a bout of diarrhoea and vomiting. He had a moderately severe haemolytic anaemia, and despite a normal platelet count there were bruises and petechiae on his limbs, and the stools showed occult blood. Bone-marrow examination showed marked erythroid hyperplasia.

In spite of the fact that there was no history of oliguria and none was noted after admission to hospital, his blood urea was $550 \mathrm{mg} . / 100 \mathrm{ml}$., and the urine was loaded with protein.

He was given a blood transfusion, followed by intravenous fluids over four days, and as haemolysis continued prednisolone was started. Haemolysis ceased on this treatment, but proteinuria decreased only temporarily, recurring after the treatment was discontinued. The blood urea fell rapidly over a period of 10 days. Proteinuria persisted for 18 months, but within this period tests of renal function in the form of urea clearance, creatinine clearance, and intravenous pyelogram showed no abnormality.

Two years from the onset of the illness he was well and all laboratory tests were normal.

Case 4. J.G., aged 15 months was admitted on July 8, 1963. She presented with convulsions occurring 6 days after an upper respiratory infection and a diarrhoeal illness. The outstanding feature was urinary suppression, and she was transferred to an artificial kidney unit where she died after dialysis.

Although anaemia was not marked, her haemoglobin being $61 \%$, the blood film showed the typical changes in the red cells. Platelets were plentiful in the film, and a platelet count at the time of dialysis was $100,000 / \mathrm{c} . \mathrm{mm}$. Uraemia was probably the cause of her convulsions but the CSF protein was $80 \mathrm{mg}$. $/ 100 \mathrm{ml}$. Necropsy showed renal cortical necrosis, and in glomeruli away from the necrotic zones the lesion appeared to be a diffuse soft thickening of the basement membrane and swelling of endothelium, with areas of fibrinoid necrosis and marked intracapillary luminal thrombosis.

Case 5. D.S., aged 10 months was admitted on July 17,1963 , suffering from a haemolytic anaemia which had been preceded by an upper respiratory infection and a diarrhoeal illness. Despite a normal platelet count there were purpuric lesions on his skin. The urine was loaded with protein, his blood urea was $130 \mathrm{mg} . / 100 \mathrm{ml}$., and a serum cholesterol, estimated because his blood was noted to be lipaemic, was $305 \mathrm{mg}$. $/ 100 \mathrm{ml}$.

Prednisolone given on admission failed to stop the haemolysis immediately, and two days later a blood

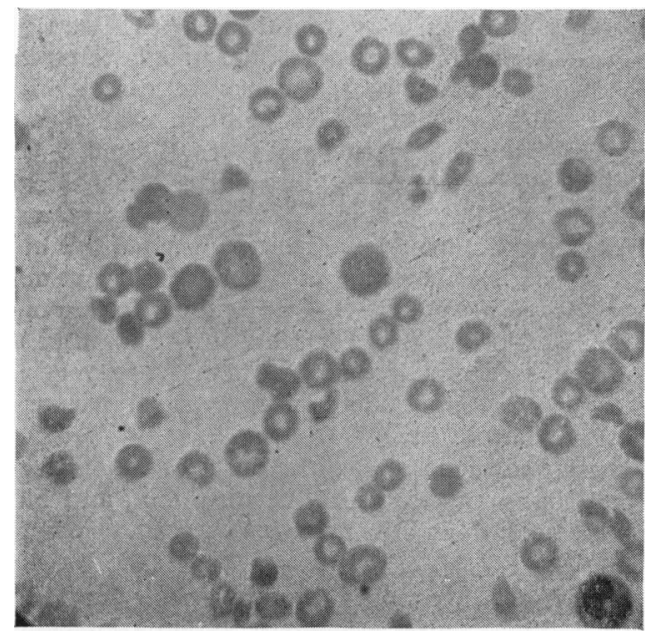

Fig. 1.-Blood film from Case 3 showing variation in size of red cells and the presence of irregularly contracted forms. $(\times 350$. 
transfusion was given. Prednisolone was continued, haemolysis stopped within a few days, proteinuria decreased while he was having prednisolone, but recurred after treatment and persisted as $1+$ proteinuria for 6 months and as a trace for 18 months.

At follow-up examination 23 months from the onset of his illness he was well, his blood pressure, haemoglobin, and blood urea were normal, and the urine was clear.

Case 6. T.W., aged 22 months, presented on July 18, 1963 with a haemolytic anaemia, purpura, and melaena, with no history of preceding illness. Despite widespread purpura, the platelet count was $345,000 /$ c.mm. The blood urea was only slightly raised to $45 \mathrm{mg} . / 100 \mathrm{ml}$., and the urine showed $1+$ proteinuria.

He responded to prednisolone and did not require blood transfusion. The blood urea returned to normal and the urine cleared rapidly. Within two months the child had recovered completely, all laboratory tests were normal, and he remained well up to 22 months from the onset of the illness.

Case 7. G.J., aged 2 years 9 months, was tras ,ferred on July 19, 1963 from an Isolation Hospital w? she had been admitted as a case of dysentery because or blood and mucus in her stools.

Stool cultures were negative. Within 5 days of admission she became noticeably pale and was found to have a haemolytic anaemia, proteinuria, and a raised blood urea. She responded rapidly to treatment with prednisolone and did not require blood transfusion. Proteinuria cleared while she was on treatment with prednisolone but recurred when treatment was stopped, and persisted for 4 months. 23 months after the onset of the illness she was well and all laboratory tests were normal.

Case 8. R.W., aged 3 years 6 months, was admitted on August 7, 1963. He presented with haemolytic anaemia following a gastro-intestinal upset. Despite a normal platelet count he had purpuric lesions on his skin. His urine was loaded with protein and the serum cholesterol was greatly raised at $448 \mathrm{mg}$. $/ 100 \mathrm{ml}$.

The haemolysis responded to prednisolone and blood transfusion was not required. Again, the proteinuria cleared almost completely while prednisolone was being given but recurred within a week of discontinuing treatment and persisted as $2+$ proteinuria for $\mathbf{8}$ months and as slight proteinuria for 18 months. Within this period, however, renal function tests in the form of urea and creatinine clearance, and an intravenous pyelogram, showed no abnormality.

Twenty-two months after the onset of the illness he was well, his blood pressure, haemoglobin, and blood urea were normal, and the urine had cleared.

Case 9. C.G., aged 11 months, was admitted on August 8, 1963, with a haemolytic anaemia following a gastro-intestinal upset, in which fresh blood had been passed in her stools. She had a few small bruises on her limbs, and her platelet count was a little reduced to
$134,000 /$ c.mm. Urine showed protein and the blood urea was $96 \mathrm{mg}$. $/ 100 \mathrm{ml}$. Serum cholesterol was $321 \mathrm{mg}$./ $100 \mathrm{ml}$.

She responded to treatment with prednisolone. No further haemolysis occurred. Proteinuria decreased while on treatment, but recurred when treatment was stopped and persisted for 6 months.

Twenty-two months after the onset of the illness she was well and all laboratory tests were normal.

Case 10. M.J., aged 10 months, was admitted on December 13, 1963, with a haemolytic anaemia following an upper respiratory infection and a gastro-intestinal illness. He had a few bruises and petechiae on his trunk and his platelets were reduced to $140,000 / \mathrm{c} . \mathrm{mm}$. Proteinuria was present, the blood urea was $138 \mathrm{mg}$./ $100 \mathrm{ml}$., and the serum cholesterol $321 \mathrm{mg} . / 100 \mathrm{ml}$.

Marked irritability was a feature of his illness. He was treated with blood transfusion and prednisolone. Haemolysis ceased and proteinuria cleared while he was having prednisolone, but recurred immediately the prednisolone was discontinued and persisted for 6 months.

Eighteen months after the onset of the illness he was well, haemoglobin, blood urea, and urine were normal.

\section{Discussion}

Clinical and laboratory features. The age range of our cases was from 6 weeks to 8 years with an average of 26 months, 2 children being over 3 years of age and 6 over 1 year. In the largest series reported, from Argentina by Gianantonio, Vitacco, Mendilaharzu, Rutty, and Mendilaharzu (1964), all 58 were under the age of 3 years, the mean age being 12.6 months, and from the published reports the majority of cases occurred in the first year of life.

Anaemia was the outstanding feature in 9 of our cases, and in all of them the red cells showed the abnormal morphology already referred to, and illustrated in Fig. 1. All authors regard the anaemia of this syndrome as haemolytic. With the exception of Case 5 of Gasser et al. the direct Coombs test has always been negative and this was so in all our cases. Inclusion bodies in the red cells have never been found. Few authors have estimated osmotic fragility: usually it has been found to be normal, but occasionally raised. We found a marked increase in 2 , and a slight increase in 3 , while in 4 it was normal. The increased fragility is presumably related to the change in morphology of the red cells, and in all our cases it returned to normal with clinical recovery.

Despite the acuteness of the haemolytic process, jaundice has usually been reported as mild or absent. It was not found in any of our children either clinically or biochemically, presumably because the intact liver is able to excrete the excess of bilirubin as it is formed. 


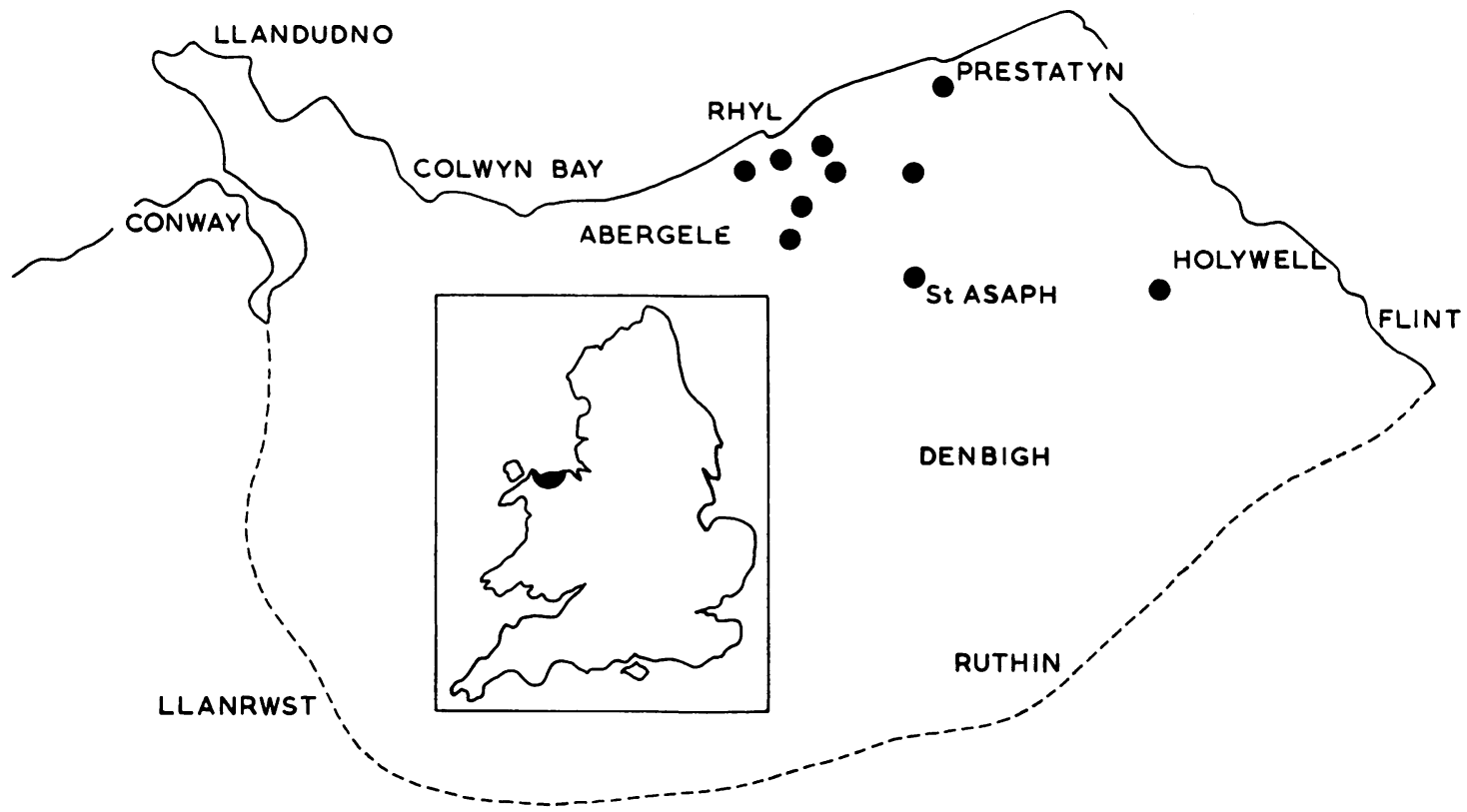

FIG. 2.-Map showing the distribution of the 10 cases (black dots) within the area of North Wales served by the hospital (shaded area in inset map).

In the original description of this syndrome, thrombocytopenia was stressed as an essential feature, and this has been accepted by most authors. Indeed, Javett and Senior (1962) rejected an otherwise typical case in which this feature was absent. In the large series reported by Gianantonio et al. (1964), 8 did not show thrombocytopenia, and 7 had only a mild reduction of platelets, with counts from 100,000 to $150,000 / \mathrm{c} . \mathrm{mm}$. We agree with these authors that thrombocytopenia is not an invariable feature of the syndrome, since only 3 of our patients had platelet counts of less than $150,000 / \mathrm{c} . \mathrm{mm}$., and these were $146,000,134,000$, and $100,000 /$ c.mm., respectively.

With the exception of Case 4, who was anuric on admission, urinary output was normal, but despite this the blood urea was above $45 \mathrm{mg}$. $/ 100 \mathrm{ml}$. in all cases, and above $70 \mathrm{mg}$. in 7 cases. All showed proteinuria, while granular and hyaline casts and leucocytes were present in the urine in some. Several had microscopical haematuria, but frank blood was seen in the urine in only the fatal case. No correlation was found between the degree of azotaemia and that of anaemia.

Few authors have estimated the serum cholesterol, but Lamvik (1962) found a level of $338 \mathrm{mg} . / 100 \mathrm{ml}$. in one case. This estimation was done in 4 of our later cases, and in all it was found to be raised, the highest reading being $448 \mathrm{mg} . / 100 \mathrm{ml}$.
The CSF was examined in 2 , in one of which xanthochromia was found and the other showed a moderate rise of protein to $80 \mathrm{mg}$. $/ 100 \mathrm{ml}$.

Hypertension has frequently been recorded, but none of our children was hypertensive during the acute illness, nor did hypertension develop later.

No pathogenic organisms, in particular no $\beta$ haemolytic streptococci were cultured from throat swabs taken in all cases on admission. Culture of faeces and urine similarly failed to reveal any pathogens. The antistreptolysin titre was not raised in any of the 9 cases in which it was estimated. In 8 cases, attempts to culture a virus from throat swabs and faeces on HeLa cells, monkey kidney, and human amnion were unsuccessful. No significant antibody titres were found to influenza $A$ B and $C$, parainfluenza, A P C group, psittacosis-L G V, sendai, mumps, L.C.M., herpes simplex, respiratory syncytial virus, Streptococcus M G, or leptospirae, and no heterophile antibody was present.

Nature of the disease. The nature of the disease is still problematical. The principal features are haemolytic anaemia and nephropathy, while in many cases thrombocytopenia has been present.

A striking feature of our cases was their occurrence in a small area within a short period of time. The hospital serves a semi-rural area of 500 square miles, but the 10 children all lived within a very 
small part of the area drained (Fig. 2), and 9 of them were admitted to hospital within a period of 8 weeks.

Cases 2 and 3 of Wile and Sturgeon (1956) occurred about the same time, Cases 2 and 3 of Javett and Senior (1962) were in hospital together, as also were their Cases 4 and 5. Two of Lamvik's (1962) cases occurred within 5 weeks of each other, and Vildosola, Bravo, and Emparanza (1962) report the syndrome occurring in sisters within 8 days of each other. Although in the large South American series cases seemed to be admitted to hospital in groups, they came from widely scattered areas (C. Gianantonio, 1964, personal communication). Kibel and Barnard (1964) draw attention to the occurrence of cases in small geographic areas. In their country, Rhodesia, cases have been described in Bulawayo, but not in the larger town of Salisbury, and in South Africa there are several reports from Johannesburg, but none from Durban or Cape Town.

The occurrence of our cases in what appeared to be epidemic form suggested to us either a toxic or an infective cause. An intensive epidemiological investigation carried out by a member of the staff of the Epidemiological Laboratory at Colindale failed to reveal any evidence of a toxic agent in the home environment. Samples of water from the homes concerned showed no abnormal constituents, and scrutiny of the children's diets showed no food which could be held responsible for the symptoms. No drugs had been taken by any of the children before the onset of the illness, though the gastrointestinal and upper respiratory symptoms had been treated with various antibiotics-neomycin, tetracycline, penicillin, and sulphonamide. None of the children had access to pesticides or played on land treated with pesticides; there are no factories with noxious effluent in the area; none of the children had sucked lead toys and no lead paints had been used in their homes.

No infective agent was isolated from our cases in bacteriological or virological studies. There was no infection present in other members of the families, no evidence of contact between the cases was discovered, and no disease was epidemic in the area at that time.

Gianantonio et al. (1964) have isolated a virus from the blood of 5 patients during the acute phase of the disease, and in 15 patients they have demonstrated significant titres to a virus isolated from one of these patients. They have not, however, been able to demonstrate these antibodies in the blood of several cases of the syndrome from another centre (Gianantonio et al., 1964).

On the basis of our experience we consider that the disease is initiated by an exogenous agent. Since it is almost invariably preceded by a gastrointestinal or respiratory illness, it seems probable that it represents a response to an infection. Although Gianantonio et al. (1964) have identified one possible causative virus, it may be that various infective agents can initiate the syndrome. The latent period between the diarrhoeal illness and the development of the haemolysis and uraemia suggests an allergic reaction, possibly of the Schwartzman type, as suggested by Shumway and Terplan (1964) and Kibel and Barnard (1964), the effect of which is to cause damage to small blood vessels including the glomeruli, the haemolysis being caused by contact with the damaged intima. Such intimal changes in vessels of the skin might explain the purpura which, in our cases, could not be attributed to a significant thrombocytopenia.

Treatment. In the presence of severe and progressive anaemia transfusion is required, and 4 of our children were so treated. No child required a second transfusion.

Opinion of the value of corticosteroids varies. We gave prednisolone in a dosage of $50 \mathrm{mg}$. daily, the dose being gradually reduced over 3 weeks, and we concluded that this was of value in controlling the haemolytic process. The influence of steroids on the renal lesion is less easy to assess, but we did find that proteinuria decreased during the 3-week course of steroid therapy and tended to reappear when treatment stopped.

It is evident from the published reports that this syndrome presents in two principal ways, either the haemolytic process or the renal failure being predominant. In cases presenting with renal failure and oliguria dialysis is imperative and should be carried out as a matter of urgency. It would seem reasonable to follow the dialysis with steroid therapy.

Prognosis. In the early descriptions this syndrome was regarded as a fatal illness. Subsequent reports have modified this view, and in the $\mathbf{1 5 0}$ cases which we have accepted from the literature, death has occurred in 64, giving an over-all mortality of $43 \%$.

In their series of 58 cases, Gianantonio et al. (1964) had 17 deaths, a mortality of $29 \%$. Death has usually been due to renal failure, and the reduced mortality achieved by these latter authors may be attributed to improvement in the management of acute renal failure. Our high survival rate, on the other hand, was probably due to the fact that 
anaemia rather than renal failure was the outstanding feature in the majority of our cases.

The prognosis appears to depend on the degree of urinary suppression in the early stages, and is not related to initial haemoglobin levels or to the level of blood urea. This was illustrated in our series. Our fatal case had anuria, and in the 9 survivors, urinary output was adequate, though azotaemia, sometimes of severe degree, was present.

The fact that benign cases of the syndrome without thrombocytopenia, as described in this paper, can occur leads us to suggest that in all children in whom the diagnosis is apparently haemolytic anaemia, the blood urea should be estimated, and similarly the blood picture should be assessed in those in whom the diagnosis is apparently acute nephritis.

\section{Summary}

Ten cases of the haemolytic-uraemic syndrome in childhood are presented, the cases occurring in a small geographical area over a short period of time.

The most common presenting feature was anaemia following a diarrhoeal illness, and all cases were found to have proteinuria and azotaemia, sometimes of severe degree.

Thrombocytopenia, described by other authors, was not present in our cases.

Blood transfusion was given in $4 ; 8$ were treated with corticosteroids, and these were thought to be of value in controlling haemolysis.

The epidemic nature of our cases suggested a toxic or infective agent, though none was discovered.

One child died with renal cortical necrosis. The 9 survivors have been followed for periods of up to two years. All are well, and show nothing abnormal.

The syndrome, particularly in its milder form, is probably commoner than the number of published cases would suggest, and should be considered in all cases of haemolytic anaemia or acute renal disease in childhood.

We wish to thank the following for their help. Mr. W. E. Portwood for the biochemical estimations; Mr. P. Smith for the haematological investigations; Mr. G. Tushingham for the photograph; Dr. Kingsley Smith and Dr. Bruce White for the virological studies; Dr. Bevan Jones and Dr. David Roberts for the epidemiological study; Dr. M. J. Bouton for the necropsy report; Dr. H. M. Goldsmith who undertook the dialysis of Case 4; and Miss Nora Perkins for secretarial help.

\section{REFERENCES}

Aherne, W. A. (1957). The 'burr' red cell and azotaemia. f. clin. Path., 10, 252.

Allison, A. C. (1957). Acute haemolytic anaemia with distortion and fragmentation of erythrocytes in children. Brit. F. Haemat., 3, 1.
Anderson, J., Lee, H. A., and Stroud, C. E. (1965). Haemodialysis in infants and small children. Brit. med. F., 1, 1405.

Debré, R., Mozziconacci, P., Brissaud, H. E., Lagrue, G., and Habib, R. (1958). Purpura thrombopénique et nephropathies. Arch. franc. Pédiat., 15, 289.

Dubois, R., Dustin, P., Bartman, J., and de Haruen, M. E. (1961). Anémie hémolytique thrombocytopénie et néphropathie. Ann. Pédiat., 37, 57.

Fison, T. N. (1956). Acute glomerulonephritis in infancy. Arch. Dis. Childh., 31, 101.

Gasser, C., Gautier, E., Steck, A., Siebenmann, R. E., and Oechslin, R. (1955). Hämolytisch-urämische Syndrome: bilaterale Nierenrindennekrosen bei akuten erworbenen hämolytischen Anämien. Schweiz. med. Wschr., 85, 905.

Gianantonio, C., Vitacco, M., Mendilaharzu, F., Rutty, A., and Mendilaharzu, J. (1964). The hemolytic-uremic syndrome. f. Pediat., 64, 478.

Griffiths, J., and Irving, K. C. (1961). A haemolytic-uraemic syndrome in infancy. Arch. Dis. Childh., 36, 500.

Grumbach, R., Drapeau, P., and Boralevi, C. (1960). Néphroanémie thrombopénique aiguë. (Forme particulière de maladie de Moschowitz) etude d'une biopsie rénale. Arch. frans. Pédiat., $17,1333$.

Hensley, W. J. (1952). Haemolytic anaemia in acute glomerulonephritis. Aust. Ann. Med., 1, 180.

Javett, S. N., and Senior, B. (1962). Syndrome of hemolysis, thrombopenia and nephropathy in infancy. Pediatrics, 29, 209.

Kibel, M. A., and Barnard, P. J. (1964). Treatment of acute haemolytic-uraemic syndrome with heparin. Lancet, 2, 259.

Lamvik, J. O. (1962). Acute glomerulonephritis with hemolytic anemia in infants. Pediatrics, 29, 224.

Leikin, S. L. (1964). Hematologic aspects of renal disease. Pediat. Clin. N. Amer., 11, 667.

Lock, S. P., and Dormandy, K. M. (1961). Red-cell fragmentation syndrome. A condition of multiple aetiology ? Lancet, $1,1020$.

Loeb, H., Bartman, J., Dustin, P., Jr., and Namèche, J. (1959). Néphropathie avec anémie hémolytique et purpura thrombocytopénique. Acta paediat. belg., 13, 111.

MacWhinney, J. B., Jr., Packer, J. T., Miller, G., and Greendyke, R. M. (1962). Thrombotic thromboyctopenic purpura in childhood. Blood, 19, 181.

Moorhead, J. F., Edwards, E. C., and Goldsmith, H. J. (1965). Haemodialysis of three children and one infant with a haemolytic-uraemic syndrome. Lancet, 1, 570.

Mozziconacci, P., Dreyfus, B., Attal, C., Girard, F., and Raynaud, E. J. (1958). Intérèt des modifications morphologiques des hématies au cours des anémies hémolytiques avec néphropathies hématuriques. Sem. Hôp. Paris, 34, 2812.

Robertson, S. E. J. (1957). Acute haemolytic anaemia associated with acute glomerulonephritis in infancy. Med.F. Aust., 2, 686.

Rosenthal, D., Schwartz, H. C., Yaffe, S. J., and Kretchmer, N. (1962). The syndrome of hemolytic anemia, thrombocytopenia and uremia. Amer. F. Dis. Child., 104, 473.

Royer, P., Habib, and Mathieu, H. (1960). La microangiopathie thrombotique de rein chez l'enfant. Sem. Hôp. Paris, 36, 572.

Sansone, G., Buffoni, L., and Rosso, C. (1961). Anemia emolitica microangiopatica trombosante nel bambino. Pathalogica, 53, 161.

Sheehan, H. L., and Moore, H. C. (1952). Renal Cortical Necrosis and the Kidney of Concealed Accidental Haemorrhage, p. 107. Blackwell, Oxford.

Shinton, N. K., Galpine, J. F., Kendall, A. C., and Williams, H. Parry (1964). Haemolytic anaemia with acute renal disease. Arch. Dis. Childh., 39, 455.

Shumway, C. N., Jr., and Miller, G. (1957). An unusual syndrome of hemolytic anemia, thrombocytopenic purpura and renal disease. Blood, 12, 1045.

_- and Terplan, K. L. (1964). Hemolytic anemia, thrombocytopenia and renal disease in childhood. Pediat. Clin. N. Amer., 11, 577.

Vildosola, S. M. J., Bravo, R. I., and Emparanza, S. E. del (1962). Sindrome hemolítico-urémico en la infancia. Pediatria (Santiago), 5, 292.

Wile, S. A., and Sturgeon, P. (1956). Thrombotic thrombocytopenic purpura. Pediatrics, 17, 882.

Zajiček, M., and Pelikăn, L. (1959). Hemolyticko-uremický syndrom. C.s. Pediat., 14, 504. 